\title{
A polymorphism in the insulin-like growth factor 1 gene is associated with postpartum resumption of ovarian cyclicity in Holstein-Friesian cows under grazing conditions
}

\author{
Paula Nicolini $i^{*}$, Mariana Carriquiry $^{2}$ and Ana Meikle ${ }^{1}$
}

\begin{abstract}
Background: Insulin-like growth factor 1 (IGF-1) gene is considered as a promising candidate for the identification of polymorphisms affecting cattle performance. The objectives of the current study were to determine the association of the single nucleotide polymorphism (SNP) IGF-1/SnaBI with fertility, milk production and body condition traits in Holstein-Friesian dairy cows under grazing conditions.

Methods: Seventy multiparous cows from a commercial herd were genotyped for the SNP IGF-1/SnaBI. Fertility measures evaluated were: interval to commencement of luteal activity (CLA), calving to first service (CFS) and calving to conception (CC) intervals. Milk production and body condition score were also evaluated. The study period extended from 3 wk before calving to the fourth month of lactation.

Results and discussion: Frequencies of the SNP /GF-1/SnaBI alleles A and B were 0.59 and 0.41 , respectively. Genotype frequencies were $0.31,0.54$ and 0.14 for $A A, A B$ and $B B$, respectively. Cows with the AA genotype presented an early CLA and were more likely to resume ovarian cyclicity in the early postpartum than $A B$ and $B B$ ones. No effect of the SNP IGF-1/SnaBl genotype was evidenced on body condition change over the experimental period, suggesting that energy balance is not responsible for the outcome of postpartum ovarian resumption in this study. Traditional fertility measures were not affected by the SNP IGF-1/SnaBI.

Conclusion: To our knowledge this is the first report describing an association of the SNP /GF-1/SnaBI with an endocrine fertility measure like CLA in cattle. Results herein remark the important role of the IGF-1gene in the fertility of dairy cows on early lactation and make the SNP /GF-1/SnaBI an interesting candidate marker for genetic improvement of fertility in dairy cattle.
\end{abstract}

Keywords: IGF-1, Polymorphism, Commencement of luteal activity, Cattle

\section{Background}

Over the last decades fertility in Holstein dairy cows has declined in coincidence with the continuing drive by breeding companies to increase genetic merit for milk production $[1,2]$. The concern of poor fertility is such that in recent years many countries have implemented genetic evaluations for fertility traits [3-5]. Traditional fertility measures, such as calving-to-first service (CFS)

\footnotetext{
* Correspondence: paula.nicolini@gmail.com

${ }^{1}$ Laboratory of Nuclear Techniques, Faculty of Veterinary Medicine, University of Uruguay, Lasplaces 1550, C.P, Montevideo 11600, Uruguay

Full list of author information is available at the end of the article
}

and calving-to-conception (CC) intervals, are difficult to use in genetic improvement programmes because: 1 ) fertility is expressed late in life, 2) reproductive records are lacking and/or have poor quality, 3) traits are not normally distributed [6], which complicates the analysis, and 4) have low heritability $(<5 \%)$ [4]. Moreover, traditional reproductive traits are highly influenced by management e.g., CFS - an indirect measure of the interval from calving to first ovulation - is affected by farmer's decisions on the timing of inseminations, which vary between herds and even between cows within the same herd [7]. 
The interval from calving to commencement of luteal activity postpartum (CLA), determined by milk progesterone $\left(\mathrm{MP}_{4}\right)$ profiles, has been suggested as a suitable selection criteria for fertility, as early CLA is an important factor for a new pregnancy after calving, CLA is free from management bias, it presents higher heritability values (16 to $25 \%$ ) than traditional fertility traits, and it is genetically favorably correlated with traditional fertility traits [8-11].

The delay in the resumption of ovarian cyclicity postpartum has been associated with a low reproductive performance in both confinement [12] and grazing systems [13]. The energy balance has a major effect on the resumption of cyclicity in the postpartum dairy cow [14]. The metabolic hormone Insulin-like growth factor 1 (IGF-1) is believed to be one of the main mediators of the effects of energy balance on the reproductive performance of the dairy cow after calving [15], since circulating concentrations of IGF-1 are highly associated to energy balance $[16,17]$, follicular growth $[18,19]$ and resumption of ovarian cyclicity [13,20-22].

Therefore, IGF-1 is considered as a promising candidate gene for the identification of molecular markers predicting reproductive performance in cattle. Nevertheless, there is a scarcity of information available on polymorphisms in bovine IGF-1 gene and their effects on economically important traits in beef and dairy cattle. The most studied IGF-1 gene variation is the single nucleotide polymorphism (SNP) IGF-1/SnaBI, in the promoter region of the gene (512-bp $5^{\prime}$ to the first codon of the first exon, GeneBank Accession No. AF017143) [23]. In dairy cattle, some studies have analyzed the association of this SNP with milk production traits [24-29]. However, studies evaluating the effect of this SNP on fertility traits in dairy cows are even more recent and scarce [28-30], with only the work from Ruprechter et al. [29] reporting a significant effect of the SNP IGF-1/SnaBI on CFS interval in primiparous Holstein-Friesian (HF) cows. To our knowledge there is no other published information showing a significant effect of this SNP on reproductive performance either in beef or dairy cattle. Based on these considerations, we examined the effects of the SNP IGF-1/SnaBI on CLA and traditional fertility measures, as well as on body condition score and production traits in multiparous HF dairy cows under a seasonally calving pasture-based system.

\section{Materials and methods}

Animals

All procedures were carried out in accordance with regulations set by the "Comisión Honoraria de Experimentación Animal (CHEA)", University of Uruguay, Uruguay. Seventy HF cows $(n=42$ Uruguayan HF (UHF), and $n=28$ UHF $x$ New Zealand HF (NZHF) first cross
(UHFxNZHF), i.e., progeny of NZHF sires) in their second $(\mathrm{L} 2, \mathrm{n}=46)$ and third $(\mathrm{L} 3, \mathrm{n}=24)$ parity, that calved with normal parturitions between late May and middle August, and that were free of detectable reproductive disorders and of clinical disease during the experimental period, were selected from a commercial farm in Uruguay. Average herd production was about $6800 \mathrm{~L} /$ cow/year.

\section{Diet}

Before and after calving, cows grazed as one herd on improved pastures (mixture of grasses and legumes) for $6 \mathrm{~h} /$ day. In addition, during ap cows were fed ad libitum a diet that consisted in whole-plant grain sorghum silage (33\% dry matter, DM; $1.1 \mathrm{MCal}$ net energy for lactation, $\mathrm{NEL} / \mathrm{kg} \mathrm{DM}, 6.8 \%$ crude protein, $\mathrm{CP})$, high moisture sorghum grain $(16 \% \mathrm{CP}, 1.5 \mathrm{MCal} \mathrm{NEL} / \mathrm{kg} \mathrm{DM})$ and a commercial mineral supplement. After calving, cows were maintained on the same ap diet and supplemented with 7 (June), 15 (July), 12 (August), 4 (September/October/ November) and 6 (December) $\mathrm{kg}$ (DM) of a commercial concentrate $(16 \% \mathrm{CP}, 1.5 \mathrm{MCal} \mathrm{NEL} / \mathrm{kg})$ which was provided once a day after the morning milking.

\section{Reproductive management}

A planned start of mating was imposed after a voluntary waiting period of 90 days from the beginning of the calving period. The breeding season extended for three months (September to November) in order to achieve a concentrated calving pattern in the following season. Artificial insemination was performed for the first two months followed by a further month of natural mating. Cows were inseminated $12 \mathrm{~h}$ after heat detection, Pregnancy diagnosis was performed by palpation per rectum 45 days after insemination.

\section{Milk and body condition score measurements}

Body condition score was performed by two trained persons according to Edmonson et al. [31] using a 5-point scale $(1=$ emaciated, $5=$ fat $)$ with quarter-point increments. Cows were scored fortnightly from $3 \mathrm{wk}$ before the expected calving date to the fourth month of lactation. The final score per cow at each time-point observation corresponded to the average value of the scores given by each scorer. Cows were milked twice daily, and milk yield and composition were determined from morning and afernoon herd-tests samples once monthly until the fourth month of lactation.

\section{Milk sampling for $\mathrm{MP}_{4}$ determination}

Milk samples for $\mathrm{P}_{4}$ determination were collected twice weekly during the morning milking. For each cow, sampling began at calving (Day 0) and extended until cyclicity was detected. In the case of one cow no detectable $\mathrm{MP}_{4}$ was observed over the study period, thus, the last 
day of sampling (around Day 120) was arbitrarily considered as the initiation of ovarian cyclicity for that cow, as previously defined by Meikle et al. [13]. Milk samples $(20 \mathrm{~mL})$ were collected into plastic tubes containing $\mathrm{NaN}_{3}$ as a preservative, refrigerated, transported to the Laboratory of Nuclear Techniques (Veterinary Faculty, Uruguay), and held at $4^{\circ} \mathrm{C}$ up to one week. Samples were skimmed by centrifugation at $3000 \mathrm{rpm}$ at $4^{\circ} \mathrm{C}$ for 15 min and skim milk samples were stored at $-20^{\circ} \mathrm{C}$ until $\mathrm{P}_{4}$ analysis. Progesterone was determined by a solid radioimmunoassay using a commercial kit (Coat-a-count, DPC, Diagnostic Products Co., Siemens, Los Angeles, CA, USA). The intra and inter-assay CVs of a medium control $(4.5 \mathrm{nmol} / \mathrm{L})$ were $5.8 \%$ and $9 \%$, respectively. The sensitivity was $0.15 \mathrm{nmol} / \mathrm{L}$.

\section{Reproductive measurements}

The endocrine fertility measure CLA interval (days, $\mathrm{n}=70$ ) was defined as the number of days from calving to the first day of luteal activity (i.e., the date of the first of two consecutive records where $\mathrm{MP}_{4}$ concentrations increased above the threshold value of $1 \mathrm{nmol} / \mathrm{L})$. Traditional fertility measures such as CFS (days, $\mathrm{n}=55$ ) and CC (days, $n=42$ ) intervals were obtained from herd's records on actual calving and service dates, and on pregnancy diagnosis data, respectively. Culling of cows due to reproductive failure reduced the original sample size to the numbers indicated in parentheses for CFS and $\mathrm{CC}$ measures.

\section{DNA extraction and SNP IGF-1/SnaBI genotyping}

Blood samples $(10 \mathrm{~mL})$ were collected from HF cows by coccygeal venipuncture in $\mathrm{K}_{2}$ EDTA Vacutainer ${ }^{\circledR}$ tubes (Becton Dickinson, NJ, USA) and stored at $4^{\circ} \mathrm{C}$ for $48 \mathrm{~h}$ until DNA isolation at the Laboratory of Nuclear Techniques, Veterinary Faculty, Uruguay. Genomic DNA was isolated from whole blood using a proteinase K/ salting out/ethanol precipitation procedure as described by Montgomery and Sise [32]. Quantity and quality of DNA were assesed using a NanoDrop ${ }^{\text {TM }}$ ND-1000 UV-vis spectrophotometer (NanoDrop Technologies, Inc., Wilmington, DE). DNA samples were stored at $-20^{\circ} \mathrm{C}$ until assayed. Cows were genotyped for the SNP IGF-1/SnaBI by the amplification of a 249-bp fragment with the primers: forward $5^{\prime}$-ATTACAAAGCTGCCTGCCCC-3' and reverse $5^{\prime}$-ACCTTACCCGTATGAAAGGAATATACGT-3', followed by digestion with SnaBI restriction endonuclease (New England Biolabs, USA), accordig to Ge et al. [23]. Analysis of the restriction fragments of A (nucleotide $T$ ) (223 and $26 \mathrm{bp}$ ) and B (nucleotide C) (undigested, $249 \mathrm{bp}$ ) alleles was performed by $3 \%$ agarose gel electrophoresis at $100 \mathrm{~V}$ for $1 \mathrm{~h}$, followed by ethidium bromide staining and UV visualization.

\section{Statistical analyses}

Allele and genotype frequencies of the SNP IGF-1/ SnaBI, as well as Hardy-Weinberg equilibrium (HWE) test and Ewens-Watterson test for neutrality were performed for each genetic strain (UHF, UHFxNZHF) and for the total sample, using the PopGene32 v1.31 program [33]. Differences in the distribution of allele and genotype frequencies between genetic strains were also estimated using the same program. All other variables were analyzed using SAS programs (SAS 2000, SAS Institute Inc., Cary, NC, USA). Univariate analyses were performed on all variables to identify outliers and inconsistencies and to verify normality of residuals. Homogeneity of variances was verified with Levene's test. Changes in body condition and milk, $4 \%$ fat-corrected milk and total solids yields (MY, FCM and TSY, respectively), were analyzed as a complete randomized design by repeated measures using the mixed procedure (PROC MIXED) with a first order autoregressive covariance structure specified. Days categorized in 20-day intervals before and after calving (Day 0), and in 31-day intervals from calving, were used as the repeated effect, respectively. The model included the fixed effects of SNP IGF-1/SnaBI genotype (AA, AB, BB), strain (UHF, UHFxNZHF), parity (L2, L3), day interval, and interactions. Calving date and body condition at calving were used as covariates. Sires were included as random effect. Fertiliy measures (CLA, CFS and $\mathrm{CC}$ intervals) were analyzed using a generalized linear model (PROC GENMOD) with a Poisson distribution and $\log$ transformation specified in a model that included the fixed effects of the SNP IGF-1/SnaBI genotype, strain, parity, and interactions. Calving date, average MY over the study period and body condition at calving were used as covariates. The Kenward-Rogers procedure was used to adjust the denominator degree of freedom to test significance level of fixed effects. Transformed estimates were back transformed for presentation. The probability of cows cycling at Day 30, 45, 60, 90 and 120 was analyzed using a generalized lineal model (PROC GENMOD) with a binomial distribution and an exchangeable covariance structure specified. Means were separated using the Tukey-Kramer procedure. Interactions were retained in the model if $\mathrm{P}<0.1$. The reduced model was used in the final analysis. All data from models are presented as least square means $(\mathrm{LSM}) \pm$ pooled standard error. For those traits significantly affected by the SNP IGF-1/SnaBI genotype, additive effects were estimated by subtracting LSMs for BB genotype from those for AA genotype; whereas dominance effects were estimated by subtracting the average of LSMs for homozygous genotypes from those for $A B$ genotype [24]. Average allele substitution effects (i.e., substitution of one allele in the population with the other allele) [34] were estimated using the same models used to estimate the genotype effects but replacing the classification 
effect of genotypes by a linear regression on the number of $\mathrm{A}$ alleles $(\mathrm{BB}=0, \mathrm{AB}=1$, or $\mathrm{AA}=2)$. Significance was set at $\mathrm{P} \leq 0.05$, and a trend towards significance was set at $\mathrm{P} \leq 0.1$.

\section{Results}

SNP IGF-1/SnaBI allele and genotype frequencies

Seventy HF cows from two genetic strains were genotyped for the SNP IGF-1/SnaBI at the $5^{\prime}$-promoter region of the IGF-1 gene. Digestion of the 249-bp PCR product with $S n a$ BI resulted in the detection of the two alleles (A and $\mathrm{B}$ ) and the three possible genotypes (AA, $\mathrm{AB}$ and $\mathrm{BB}$ ) for this SNP (Figure 1). Genotype AA (TT) was characterized by the presence of one restriction fragment of 223-bp, whereas genotype AB (TC) presented two bands of 249- and 223-bp. In both cases, the 26-bp band was undetectable in the electrophoresis. The PCR product from the homozygous genotype $\mathrm{BB}(C C)$ remained undigested at 249-bp. Allele and genotype frequencies of the SNP IGF-1/SnaBI calculated for each genetic strain, as well as for the total sample, are shown in Table 1. The A allele and the $\mathrm{AB}$ genotype were the most frequent in both genetic groups. Genotype frequencies tended to differ between these groups $(\mathrm{P}=0.1)$, with UHF cows showing higher frequencies of the $A B$ genotype and lower frequencies of the $\mathrm{BB}$ genotype than UHFxNZHF group (Table 1). Although frequency of the $B$ allele was lower in the UHF group than in UHFxNZHF cows, differences did not reach significance $(P=0.18)$. The SNP IGF-1/SnaBI genotype frequencies conformed to HWE proportions for the UHFxNZHF strain and the total sample (Table 1). However, this locus tended to deviate from HWE in the UHF sample, which tended to exhibit more cows with the heterozygous genotype than expected (Table 1). Nevertheless, results from the Ewens-Waterson test did not assess departure from neutrality in this sample, relative to the $95 \%$ CI for expected homozygosity at the locus.

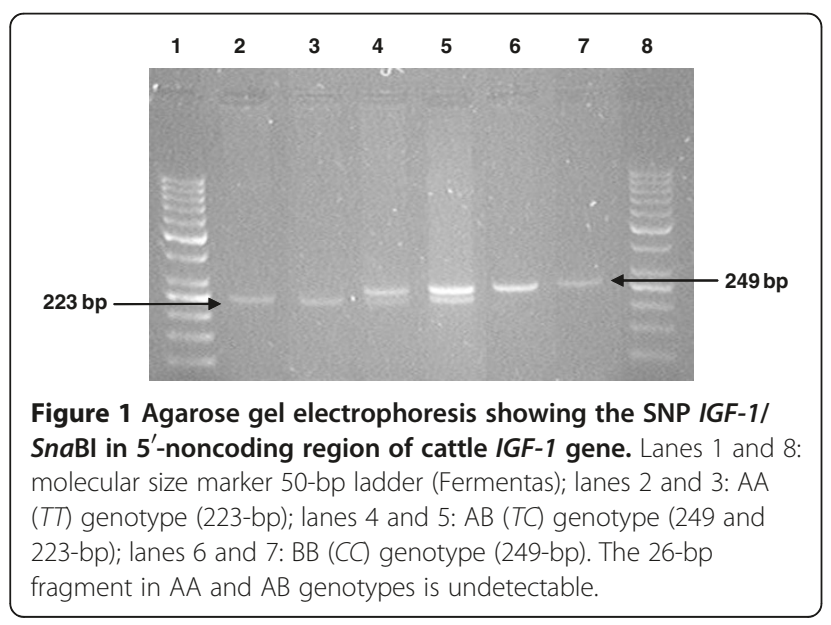

Table 1 Allele and genotype frequencies observed for the SNP IGF-1/SnaBI in Holstein-Friesian cows

\begin{tabular}{cccc}
\hline SNP IGF-1/SnaBI & UHF $^{\mathbf{1}}$ & UHFxNZHF $^{2}$ & Total $^{\mathbf{3}}$ \\
\hline allele frequencies & & & \\
A & 0.63 & 0.52 & 0.59 \\
B & 0.37 & 0.48 & 0.41 \\
genotype frequencies & & & \\
AA & $0.33(14)$ & $0.28(8)$ & 0.31 \\
AB & $0.59(25)$ & $0.46(13)$ & 0.54 \\
BB & $0.07(3)$ & $0.25(7)$ & 0.14
\end{tabular}

UHF: Uruguayan Holstein-Friesian cows; UHFxNZHF: UHF x New Zealand Holstein-Friesian first cross cows. ${ }^{1,2,3}$ Hardy-Weinberg Equilibrium test: $\chi^{2}=2.98$, $\mathrm{P}=0.08 ; X^{2}=0.22, \mathrm{P}=0.64 ; X^{2}=0.87, \mathrm{P}=0.35$, respectively. The number of animals per genotype is indicated in parentheses.

\section{Body condition score and milk production}

Neither body condition score nor milk production traits were affected by the SNP IGF-1/SnaBI genotype or strain. Body condition score declined $(\mathrm{P}<0.0001)$ around calving (3.2 \pm 0.03 points), reached its lowest value around Day 45 (2.8 \pm 0.03 points), and started to recover at Day 95 $(2.9 \pm 0.03$ points).

\section{Fertility measures}

Significant genotype, additive and allele substitution effects of the SNP IGF-1/SnaBI were observed on interval to CLA, with homozygous AA genotype being more favorable for this trait (Table 2). Cows carrying the AA genotype resumed postpartum ovarian cyclicity on average $\sim 15$ and 33 days earlier than $\mathrm{AB}$ and $\mathrm{BB}$ ones, respectively; in addition, $A B$ cows tended to exhibit shorter intervals than $\mathrm{BB}$ ones (Table 2). A trend for a dominance effect of the A allele was observed, as heterozygous cows presented shorter intervals to CLA than the average for homozygous cows (Table 2). No strain or parity effects were observed on CLA. No effect of either body condition at calving, average MY over the study period or calving date (covariates) were observed on CLA.

Probability of cows cycling was affected by the SNP IGF-1/SnaBI genotype on Day $30(\mathrm{P}=0.01), 45(\mathrm{P}=0.02)$ and $60(\mathrm{P}=0.06)$, but not on Day 90 (Figure 2). Cows with AA genotype were more likely to resume ovarian cyclicity in the early postpartum period (before Day 45) than those with $\mathrm{AB}$ or $\mathrm{BB}$ genotypes. Differences between $\mathrm{AA}$ and $\mathrm{BB}$ cows were significant on Day 30, 45 and 60. The AA genotype tended to present more cows cycling than $\mathrm{AB}$ genotype on Day $30(P=0.07)$ and $45(P=0.1)$, whereas a trend was observed for the $A B$ genotype showing more cows cycling than the $\mathrm{BB}$ genotype on Day $30(\mathrm{P}=0.1), 45$ $(\mathrm{P}=0.08)$ and $60(\mathrm{P}=0.1)$.

Neither CFS nor CC interval was affected by the SNP $I G F-1 / S n a B I$ genotype, strain or parity (Table 2). Average milk yield over the study period (covariate) did not affect CFS, but tended to affect $C C$ interval $(P=0.09)$, 
Table 2 Least square means ( \pm pooled standard error) of SNP IGF-1/SnaBI-associated effects on productive and reproductive traits in Holstein-Friesian cows

\begin{tabular}{|c|c|c|c|c|c|c|c|c|c|}
\hline & \multicolumn{3}{|c|}{ SNP IGF-1/SnaBI genotype } & \multirow{2}{*}{$\begin{array}{c}\text { Additive } \\
\text { effect }\end{array}$} & \multirow[t]{2}{*}{ P-value } & \multirow{2}{*}{$\begin{array}{l}\text { Dominance } \\
\text { effect }\end{array}$} & \multirow[t]{2}{*}{ P-value } & \multirow{2}{*}{$\begin{array}{c}\text { Allele } \\
\text { substitution } \\
\text { effect }\end{array}$} & \multirow[t]{2}{*}{ P- value } \\
\hline & AA & $A B$ & BB & & & & & & \\
\hline \multicolumn{10}{|l|}{ Production $^{1}(\mathrm{n}=70)$} \\
\hline Milk Yield (L/cow) & $25.4 \pm 0.7$ & $26.3 \pm 0.5$ & $25.7 \pm 1.1$ & - & - & - & - & - & - \\
\hline 4\% Fat-Corrected Milk (L/cow) & $22.8 \pm 0.7$ & $23.4 \pm 0.5$ & $23.8 \pm 0.9$ & - & - & - & - & - & - \\
\hline Total Solids Yield (kg/cow) & $2.9 \pm 0.1$ & $2.9 \pm 0.06$ & $2.9 \pm 0.1$ & - & - & - & - & - & - \\
\hline \multicolumn{10}{|l|}{ Fertility (days) } \\
\hline Calving-CLA $(n=70)$ & $35.0 \pm 6.0^{\mathrm{ax}}$ & $49.8 \pm 4.5^{\mathrm{bx}}$ & $67.8 \pm 8.6^{\text {by }}$ & $-32.8 \pm 10.5$ & 0.003 & $-1.6 \pm 9.8$ & 0.07 & $-16.0 \pm 5.0$ & 0.002 \\
\hline Calving-First Service $(n=55)$ & $83.2 \pm 4.5$ & $81.6 \pm 3.3$ & $79.0 \pm 6.7$ & - & - & - & - & - & - \\
\hline Calving-Conception ( $n=42)$ & $90.8 \pm 5.5$ & $86.7 \pm 3.7$ & $92.0 \pm 7.0$ & - & - & - & - & - & - \\
\hline
\end{tabular}

${ }^{1}$ Production traits represent the first four months of lactation. CLA: commencement of luteal activity. Means with different superscripts within the same row differ: a vs $b$ P $\leq 0.04$, $x$ vs y $P \leq 0.09$.

as cows with shorter intervals tended to have higher production.

\section{Discussion}

The SNP IGF-1/SnaBI has been studied in about 30 cattle breeds, including dairy and beef breeds [23,24,27,28,35-38]. In the current study, allele frequencies of the SNP IGF-1/SnaBI estimated for the UHFxNZHF group (A: 0.52, B: 0.48) as well as for the total sample (A: 0.59 , B: 0.41), are in agreement with those previously published in North American (NA) [24], Polish [25], and Uruguayan [29] HF populations (A: 0.55, 0.52 and $0.60 ; \mathrm{B}: 0.45,0.48$ and 0.40 , respectively). On the other hand, allele frequencies in the sample of UHF cows tended to present a different distribution (A: 0.63, B: 0.37), which is similar to that (A: $0.64, \mathrm{~B}: 0.36$ ) reported by Ge et al. [23] in Angus beef cattle. In our study, the sample of UHF cows tends to deviate from HWE due to a heterozygote

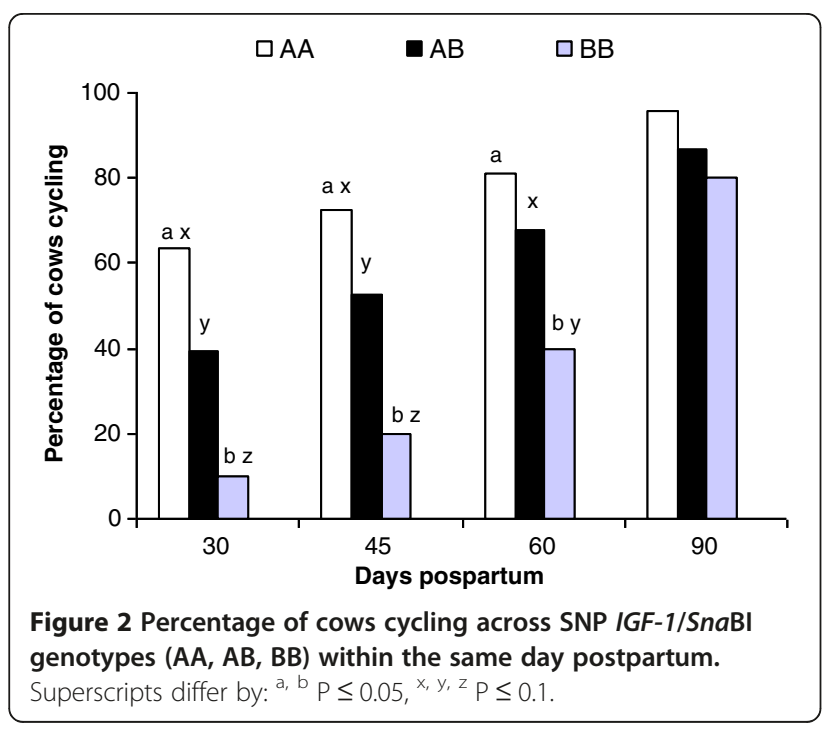

excess. Reasons for this tendency could be genetic drift or the action of selection acting on this sample; however, no action of selection on the IGF-1 locus was evidenced in our study. Likewise, deviations from HWE were reported for the IGF-1 locus in both beef and dairy cattle $[39,40]$ and, in particular, for the SNP IGF-1/SnaBI in HF populations $[27,36]$. Furthermore, evidence of selection acting on the IGF-1 locus were found in Swedish and Polish HF populations [36], as well as in the brazilian Canchim beef cattle breed [39]. However, evidence of selection acting on this locus might be even greater provided it has not been investigated in most published works on cattle IGF-1 polymorphisms.

Our results from association analyses of the SNP IGF1/SnaBI with milk production traits show no significant effects of this SNP on either MY, FCM or TSY within the first four months of lactation. This is in accordance with previous reports that failed to observe any significant association between the SNP IGF-1/SnaBI and dairy production traits in HF cattle [24,28]. On the other hand, results from Mehmannavaz et al. [27] proved a significant effect of the SNP IGF-1/SnaBI on estimated breeding values (EBV) for milk production traits in Iranian Holstein bulls, as animals with $A B$ genotype had higher EBV for milk and fat yields than homozygous genotypes. In addition, Siadkowska et al. [25] and Bonakdar et al. [26] reported associations between the $A B$ genotype and higher percentage of milk fat and protein in Polish and Iranian HF cows, respectively. Likewise, previous studies from our group have shown that $A B$ cows tended to yield more $\mathrm{FCM}$ than primiparous $\mathrm{BB}$ cows at early and middle lactation and than multiparous AA cows over the lactation period [29]. No other reports were found in the literature concerning the effect of the SNP IGF-1/SnaBI on milk production traits.

The results of the present study further indicate a significant association of the SNP IGF-1/SnaBI with 
interval to CLA. Cows with the AA genotype present a shorter interval to CLA and are more likely to resume ovarian cyclicity in the early postpartum than $\mathrm{AB}$ and $\mathrm{BB}$ ones. Potential mechanisms for an association between the SNP IGF-1/SnaBI and the traits of interest may lie in its location in the promoter region of the IGF-1 gene and its possible influence on transcription factor binding sites and on gene expression $[28,41,42]$. Higher IGF-1 blood levels have been found in cows exhibiting shorter CLA intervals $[13,43]$. Association studies between the SNP IGF-1/SnaBI and plasma IGF-1 concentration in cattle are contradictory. Ge et al. [23] reported lower IGF-1 levels in young BB Angus bulls, while Maj et al. [41] and Mirzaei et al. [42] found higher IGF-1 concentrations in BB Polish and Iranian HF cattle, and Ruprechter et al. [29] reported no association in Uruguayan HF cows. Inconsistences among studies may be explained by IGF-1 having different effects according to breeds, stages of growth, physiological states and nutritional status, as it is known that IGF-1 gene expression is developmentally and physiologically regulated [44].

Circulating IGF-1 concentrations are temporarily affected by the negative energy balance, which in dairy cows dramatically changes during the transition period. Meikle et al. [13] reported that, under grazing conditions, lean cows with reduced serum IGF-1 concentrations presented prolonged postpartum anestrus, showing that circulating IGF-1 levels are good indicators of the re-initiation capacity after calving, which is in accordance with others $[45,46]$. In our study, although $\mathrm{AA}$ and $\mathrm{AB}$ cows presented shorter anestrus periods than $\mathrm{BB}$ ones, no differences were observed in body condition at calving among them. Moreover, differences in body condition change during the experimental period were not evidenced among genotypes, which suggests that energy balance measured by changes in body condition do not explain the differences observed among the SNP IGF-1/SnaBI genotypes on CLA interval after calving. In addition, the lack of a significant effect of milk yield on CLA could be consider as a further evidence that the energy balance is not responsible for the outcome of postpartum ovarian resumption in this study.

Although our results showed an effect of the SNP IGF-1/SnaBI on CLA, no effect was observed on traditional fertility measures like CFS and CC intervals. This is in agreement with the fact that CLA reflects more directly the reproductive physiology of the cow, being more influenced by the cow itself than traditional fertility measures [47], which are highly influenced by management and farmer's decisions [7]. Nevertheless, sample sizes analyzed in this study for traditional traits are insuficient to get to concluding results. To our knowledge this is the first report describing an association of the SNP IGF-1/ SnaBI with an endocrine fertility measure like CLA in cattle. These results are consistent with findings from a previous work of our group in another HF herd [29], where longer CFS intervals were found in primiparous $\mathrm{BB}$ cows. In contrast, other studies have failed to identify any association of the SNP IGF-1/SnaBI with endocrine or traditional fertility traits in cattle $[28,30]$. No other reports were found in the literature concerning the effects of this SNP or other SNPs at the IGF-1 gene on fertility traits in cattle.

\section{Conclusions}

Our results indicate a significant association of the SNP IGF-1/SnaBI with interval to CLA in HF dairy cows in a pasture-based system. Results herein remark the important role of the IGF-1gene in the fertility of dairy cows on early lactation and make the SNP IGF-1/SnaBI an interesting candidate marker for genetic improvement of fertility in dairy cattle.

\section{Abbreviations}

CC: Calving to conception interval; CFS: Calving to first service interval; CLA: Interval to commencement of luteal activity; CP: Crude protein; DM: Dry matter; EBV: Estimated breeding values; FCM: Fat corrected milk; HWE: HardyWeinberg equilibrium; IGF-1: Insulin-like growth factor 1; L2: Second parity; L3: Third parity; LSM: Least square means; MP: Milk progesterone; MY: Milk yield; NEL: Net energy for lactation; NZHF: New Zealand Holstein-Friesian; SNP: Single nucleotide polymorphism; TSY: Total solids yield; UHF: Uruguayan Holstein-Friesian; UHFxNZHF: UHF x NZHF first cross.

\section{Competing interests}

The authors declare that they have no competing interests.

\section{Authors' contributions}

PN contributed with the experimental design, carried out the hormone determinations and genotyping, and drafted the manuscript. MC contributed with the statistical analysis and manuscript corrections. AM lead the experimental design, contributed with data interpretation, statistical analysis and manuscript corrections. All authors read and approved the final manuscript.

\section{Acknowledgements}

This work was financially supported by the National Institute of Agricultural Research to A.M. (INIA FPTA 214),

\section{Author details}

'Laboratory of Nuclear Techniques, Faculty of Veterinary Medicine, University of Uruguay, Lasplaces 1550, C.P. Montevideo 11600, Uruguay. ${ }^{2}$ Faculty of Agronomy Sciences, University of Uruguay, Av. Garzón 780, C.P, Montevideo 12900, Uruguay.

Received: 13 November 2012 Accepted: 26 January 2013

Published: 14 February 2013

\section{References}

1. Royal MD, Darwash AO, Flint APF, Webb R, Woolliams JA, Lamming GE: Declining fertility in dairy cattle: changes in traditional and endocrine parameters of fertility. Anim Sci 2000, 70:487-501.

2. Lucy MC: Reproductive loss in high-producing dairy cattle: where will it end? J Dairy Sci 2001, 84:1277-1293.

3. Linde B, Philipsson J: The Scandinavian experience of including fertility in breeding programmes. Galway, Ireland: British Society of Animal Science BSAS Occasional Publication; 2001.

4. Wall E, Brotherstone S, Woolliams JA, Banos G, Coffey MP: Genetic evaluation of fertility using direct and correlated traits. J Dairy Sci 2003, 86:4093-4102 
5. Jorjani $\mathrm{H}$ : Preliminary report of interbull pilot study for female fertility traits in Holstein populations. Interbull Bulletin 2005, 33:34-44.

6. VanRaden PM: Normality and skewness of genetic evaluations. Interbull Bulletin 2006, 35:164-167.

7. DeJarnette JM, Sattler CG, Marshall CE, Nebel RL: Voluntary waiting period management practices in dairy herds participating in a progeny test program. J Dairy Sci 2007, 90:1073-1079.

8. Darwash AO, Lamming GE, Woolliams JA: Estimation of genetic variation in the interval from calving to postpartum ovulation of dairy cows. J Dairy Sci 1997, 80:1227-1234

9. Darwash AO, Lamming GE, Woolliams JA: The phenotypic association between the interval to postpartum ovulation and traditional measures of fertility in dairy cattle. Anim Sci 1997, 65:9-16.

10. Royal MD, Flint APF, Woolliams JA: Genetic and phenotypic relationships among endocrine and traditional fertility traits and production traits in Holstein-Friesian dairy cows. J Dairy Sci 2002, 85:958-967.

11. Petersson KJ, Berglund B, Strandberg E, Gustafsson H, Flint AP, Woolliams $J A$, Royal MD: Genetic analysis of postpartum measures of luteal activity in dairy cows. J Dairy Sci 2007, 90:427-434.

12. Staples CR, Thatcher WW, Clark JH: Relationship between ovarian activity and energy status during the early postpartum period of high producing dairy cows. J Dairy Sci 1990, 73:938-947.

13. Meikle A, Kulcsar M, Chilliard Y, Febel H, Delavaud C, Cavestany D, Chilibroste P: Effects of parity and body condition score at calving on endocrine and reproductive parameters of the dairy cow under grazing conditions. Reproduction 2004, 127:727-737.

14. Lucy MC: Mechanisms linking nutrition and reproduction in postpartum cows. Reproduction 2003, 61(Suppl):415-427.

15. Zulu VC, Nakao T, Sawamukai Y: Insulin-like growth factor-I as a possible hormonal mediator of nutritional regulation of reproduction in cattle. J Vet Med Sci 2002, 64:657-665.

16. Pushpakumara PGA, Gardner NH, Reynolds CK, Beever DE, Wathes DC Relationships between transition period diet, metabolic parameters and fertility in lactating dairy cows. Theriogenology 2003, 60:1165-1185.

17. Fenwick MA, Llewellyn S, Fitzpatrick R, Kenny DA, Murphy JJ, Patton J, Wathes DC: Negative energy balance in dairy cows is associated with specific changes in IGF-binding protein expression in the oviduct. Reproduction 2008, 135:63-75.

18. Spicer $\sqcup$, Echternkamp SE: The ovarian insulin and insulin-like growth factor system with an emphasis on domestic animals. Domest Anim Endocrinol 1995, 12:223-245.

19. Gong JG: Influence of metabolic hormones and nutrition on ovarian follicle development in cattle: practical implications. Domest Anim Endocrinol 2002, 23:229-241.

20. Beam SW, Butler WR: Effects of energy balance on follicular development and first ovulation in postpartum dairy cow. $J$ Reprod Fert 1999, 54(Suppl):411-424

21. Huszenicza GY, Kulcsar M, Nikolic JA, Schmidt J, Korodi P, Katai L, Dieleman S, Ribiczei-Szabo P, Rudas P: Plasma leptin concentration and its interrelation with some blood metabolites, metabolic hormones and the resumption of cyclic ovarian function in postpartum dairy cows supplemented with Monensin or inert fat in feed. In Fertility in the high-producing dairy cow. Edited by Diskin MG. Edinburgh: British Society of Animal Science; 2001:405-409.

22. Konigsson K, Savoini G, Govoni N, Invernizzi G, Prandi A, Kindahl H, Veronesi MC: Energy balance, leptin, NEFA and IGF-I plasma concentrations and resumption of post partum ovarian activity in swedish red and whitebreed cows. Acta Vet Scand 2008, 50:3-10.

23. Ge W, Davis ME, Hines HC, Irvin KM, Simmen RCM: Association of genetic markers with blood serum insulinlike growth factor-I concentration and growth traits in Angus cattle. J Anim Sci 2001, 79:1757-1762.

24. Hines $\mathrm{HC}$, Ge W, Zhao Q, Davis ME: Association of genetic markers in growth hormone and insuline-like groth factor I loci with lactation traits in Holsteins. Anim Genet 1998, 29:69.

25. Siadkowska E, Zwierzchowski L, Oprzadek J, Strzalkowska N, Bagnicka E, Kryzewski J: Effect of polymorphism in IGF-1 gene on production traits in Polish Holstein-Friesan cattle. Anim Sci P 2006, 24:225-237.

26. Bonakdar E, Rahmani HR, Edriss MA, Sayed Tabatabaei BE: IGF-I gene polymorphism, but not its blood concentration, is associated with milk fat and protein in Holstein dairy cows. Genet Mol Res 2010, 9:1726-1734.
27. Mehmannavaz $Y$, Amirinia C, Bonyadi M, Vaez Torshizi R: Association of IGF-1 gene polymorphism with milk production traits and paternal genetic trends in Iranian Holstein bulls. Afr J Microbiol Res 2010, 4:110-114.

28. Mullen MP, Berry DP, Howard DJ, Diskin MG, Lynch CO, Giblin L, Kenny DA, Magee DA, Meade KG, Waters SM: Single nucleotide polymorphisms in the insulin-like growth factor 1 (IGF-1) gene are associated with performance in Holstein-Friesian dairy cattle. Front Genet 2011, 2:3.

29. Ruprechter G, Carriquiry M, Ramos JM, Pereira I, Meikle A: Metabolic and endocrine profiles and reproductive parameters in dairy cows under grazing conditions: effect of polymorphisms in somatotropic axis genes. Acta Vet Scand 2011, 53:35-44.

30. Shirasuna K, Kawashima C, Murayama C, Aoki Y, Masuda Y, Kida K, Matsui M, Shimizu T, Miyamoto A: Relationships between the first ovulation postpartum and polymorphism in genes relating to function of immunity, metabolism and reproduction in high-producing dairy cows. J Reprod Dev 2011, 57:135-142.

31. Edmonson AJ, Lean LJ, Weaver LD, Farver T, Webster G: A body condition scoring chart for Holstein dairy cows. J Dairy Sci 1989, 72:68-78.

32. Montgomery GW, Sise JA: Extraction of DNA from sheep white blood cells. N Z J Agric Res 1990, 33:437-441.

33. Yeh CF, Yang R, Boyle T: PopGene version 1.31. Microsoft Window-based freeware for population genetic analysis; 1999. http:/www.alberta.ca/ fyeh/.

34. Falconer DS, Mackay TFC: Introduction to quantitative genetics. 4th edition. Harlow, Essex, UK: Longmans Green; 1996.

35. Curi RA, de Oliveira HN, Silveira AC, Lopes CR: Association between IGF-1, IGF-1R and GHRH gene polymorphisms and growth and carcass traits in beef cattle. Livest Prod Sci 2005, 94:159-167.

36. Li C, Basarab J, Snelling WM, Benkel B, Murdoch B, Hansen C, Moore SS: Assessment of positional candidate genes myf5 and igf 1 for growth on bovine chromosome 5 in commercial lines of Bos taurus. J Anim Sc 2004, $82: 1-7$.

37. Islam KK, Vinsky M, Crews RE, Okine E, Moore SS, Crews DH, Li C: Association analyses of a SNP in the promoter of IGF1 with fat deposition and carcass merit traits in hybrid, Angus and Charolais beef cattle. Anim Genet 2009, 40:766-769.

38. De la Rosa Reyna XF, Montoya HM, Castrellón W, Rincón AMS, Bracamonte MP, Vera WA: Polymorphisms in the IGF1 gene and their effect on growth traits in Mexican beef cattle. Genet Mol Res 2010, 9:875-883.

39. Regitano LCA, Azevedo JL, Vencovsky R, Packer IU, Barbosa PF, Rosa AJM, Silva NA, Etchegaray MAL, Coutinho LL: Selection for breed-specific growth hormone and IGF-I alleles in a synthetic beef cattle cross. Canchim. Genet Mol Biol 1999, 22:531-537.

40. Mullen MP, Lynch CO, Waters SM, Howard DJ, O'Boyle P, Kenny DA, Buckley F, Horan B, Diskin MG: Single nucleotide polymorphisms in the growth hormone and insulin-like growthfactor-1 genes are associated with milk production, body condition score and fertility traits in dairy cows. Genet Mol Res 2011, 10:1819-1830.

41. Maj A, Snochowski M, Siadcowska E, Rowinska B, Lisowski P, Robajowska-Hyzorek D, Oprzadek J, Grochowska R, Kochman K, Zwierzchowski L: Polymorphism in genes of growth hormone receptor (GHR) and insulin-like growth factor-1 (IGF1) and its association with both the IGF1 expression in liver and its level in blood in Polish Holstein-Friesian cattle. Neuro Endocrinol Lett 2008, 29:981-989

42. Mirzaei A, Sharifiyazdi H, Ahmadi MR, Ararooti T, Rowshan Ghasrodashti A, Kadivar A: The effect of polymorphism in gene of insulin-like growth factor-I on the serum periparturient concentration in Holstein dairy cows. Asian Pac J Trop Biomed 2012, 2:765-769.

43. Tamadon A, Kafi M, Saeb M, Mirzaei A, Saeb S: Relationships between insulin-like growth factor-l, milk yield, body condition score, and postpartum luteal activity in high-producing dairy cows. Trop Anim Health Prod 2011, 43:29-34

44. Werner H, Adamo M, Roberts $\mathrm{CT} \mathrm{Jr}$, Eroith DL, Gerald L, Werner, et al: Molecular and cellular aspects of insulin-like growth factor action. In Vitamins and Hormones, Volume 48. Edited by Litwack G. Oxford: Elsevier; 1994:1-58.

45. Roberts AJ, Nugent RA, Klindt J, Jenkins TG: Circulating insulin-like growth factor 1, insulin-like growth factor binding proteins, growth hormone, 
and resumption of oestrous in postpartum cows subjected to dietary energy restriction. J Anim Sci 1997, 75:1909-1917.

46. Butler WR: Nutritional interactions with reproductive performance in dairy cattle. Anim Reprod Sci 2000, 60:449-457.

47. Petersson KJ, Strandberg E, Gustafsson H, Berglund B: Environmental effects on progesterone profile measures of dairy cow fertility. Anim Reprod Sci 2006, 91:201-214.

doi:10.1186/1751-0147-55-11

Cite this article as: Nicolini et al:: A polymorphism in the insulin-like growth factor 1 gene is associated with postpartum resumption of ovarian cyclicity in Holstein-Friesian cows under grazing conditions. Acta Veterinaria Scandinavica 2013 55:11.

\section{Submit your next manuscript to BioMed Central and take full advantage of:}

- Convenient online submission

- Thorough peer review

- No space constraints or color figure charges

- Immediate publication on acceptance

- Inclusion in PubMed, CAS, Scopus and Google Scholar

- Research which is freely available for redistribution 